\title{
Groundwater dependent ecosystem mapping: the role of modelling in defining GDE under varying land use and climate
}

\author{
Hocking, M.J. ${ }^{1}$ and C. Beverly ${ }^{2}$ \\ ${ }^{1}$ Hocking et. al., P.O Box 369 Hampton, Victoria. \\ ${ }^{2}$ Department of Primary Industries, RMB 1145 Rutherglen, Victoria. \\ Email: mark@hockingetal.com
}

\begin{abstract}
This paper describes a proposed approach to enhance potential GDE mapping to likely GDE extent by the application of a physically-based groundwater model. The paper also compares the estimated change in shallow watertable area and, by association, the change in GDE extent under pre-European conditions and under 2030 climate change conditions.

The objectives of this paper are to (1) describe the groundwater model used which accounts for land use recharge and evapotranspiration plus surface water/groundwater interactions (2) analyse the simulated depth to watertable surface with pre-existing potential GDE mapping and (3) to present a supplementary methodology for better defining GDE map units. The impact on GDE extent under climate change and preEuropean vegetation conditions are also considered.

The paper presents a linked surface-water/groundwater catchment model (Catchment Analysis Tool, CAT) to describe the temporal soil moisture profile and groundwater dynamics within the Loddon Catchment of North Central Victoria. Results indicate that the current potential GDE mapping techniques have a high correlation with vegetation transpiration from the unsaturated zone and soil moisture status within the root zone, but poorly correlate with simulated depth to watertable. This paper concludes that the extent of existing potential GDE mapping is more than double the likely GDE extent based on estimates derived using a distributed groundwater model.

The application of a distributed groundwater model is shown to provide a more robust representation of the likely locations of a GDE when used in conjunction with the existing potential GDE layer. The reduction in the area of likely GDE assuming a dry period (2030 climate change) and pre-European landuse relative to current environmental conditions is estimated to be a factor of 1.4 and 2.2 respectively.
\end{abstract}

Keywords: Groundwater Dependent Ecosystem, GDE, catchment model, water balance, groundwater, evapotranspiration, water logging, rooting depth 


\section{INTRODUCTION}

The concept of Groundwater Dependent Ecosystems (GDEs) is generally well accepted by the scientific community. GDEs are associated with the discharge of groundwater from the catchment water balance. The degree of groundwater dependence varies, relying on groundwater intermittently or continually. Six types of GDEs have been identified in Australia (SKM 2000);

- River baseflow systems where groundwater discharge has a baseflow component to the river,

- Terrestrial vegetation that relies on the availability of shallow groundwater,

- Wetlands such as paperbark swamp forests and mound springs

- Terrestrial fauna, both native and introduced species that rely on groundwater as drinking water,

- Aquifer and cave ecosystems where life exists independent of sunlight, and

- Estuarine and near-shore marine systems, such as coastal mangroves, salt marshes and sea-grass beds which rely on the submarine discharge of groundwater.

Awareness that groundwater and surface water (and evapotranspiration) act as an interconnected system has driven a need to define and manage water as a single feature. Recently, GDE management has been written into water management plans (Parsons and Caruso, 2010). The implication of such changes in management is the requirement to monitor and evaluate GDE health. As the demand to locate where ecosystems depend on groundwater increases, differing approaches to identifying GDE should be considered.

The connection between the conceptualisation of a GDE and a standardised approach in mapping a GDE (or potential GDE) extent across Australia is less accepted. Further compounding the issue is the loss of the term "potential" from potential GDE mapping, which leads to the assumption that potential GDE mapping is actual extent rather that possible GDE.

Most potential GDE mapping focuses on defining GDEs based on estimating plant water use from remotesensed data and combining with locally interpreted groundwater-surface water interaction, whereby the underpinning assumption is that if remote-sensing identifies evapotranspiration occurring in summer, the vegetation must be in connection with groundwater. This paper aims to compare areas identified as potentially groundwater dependent with depth to watertable, soil moisture and evapotranspiration estimates derived using the process-based Catchment Analysis Tool (CAT) (Beverly et al., 2005) linked with a distributed groundwater model in the Loddon Catchment of Northern Victoria.

\section{BACKGROUND}

The Loddon Catchment (Figure1) encompasses approximately 611,316 hectares with the main land uses being dryland grazing, production forestry and cropping. There is significant variation in elevation ranging from $105 \mathrm{~m} \mathrm{AHD}$ in the north and $823 \mathrm{~m}$ AHD in the south. Mean annual rainfall similarly varies from $410 \mathrm{~mm} /$ year in the north to 1170 $\mathrm{mm} /$ year in the southern upland regions of the catchment. Further details of the hydrogeological conceptualisation and groundwater model calibration can be found in Beverly et al. (2008) and Beverly and Hocking (2009). In this application, a six layer MODFLOW groundwater model was developed and calibrated. Surface hydrology and drainage features were also incorporated into the model. Importantly, spatial land use information was explicitly incorporated into both the surface hydrologic and groundwater recharge modelling. The MODFLOW evaporation module was modified to match the rooting depths adopted from farming system models. Additionally, the evaporation depths and rates were spatially assigned to match the surface hydrologic model parameterisation. Measured versus observed calibration statistics of were found to be; a scale root mean square of $1.94 \%$, mean sum of residuals of 7.43 metres and coefficient of determination to be 1.03 with a mass balance error of $0.2 \%$.

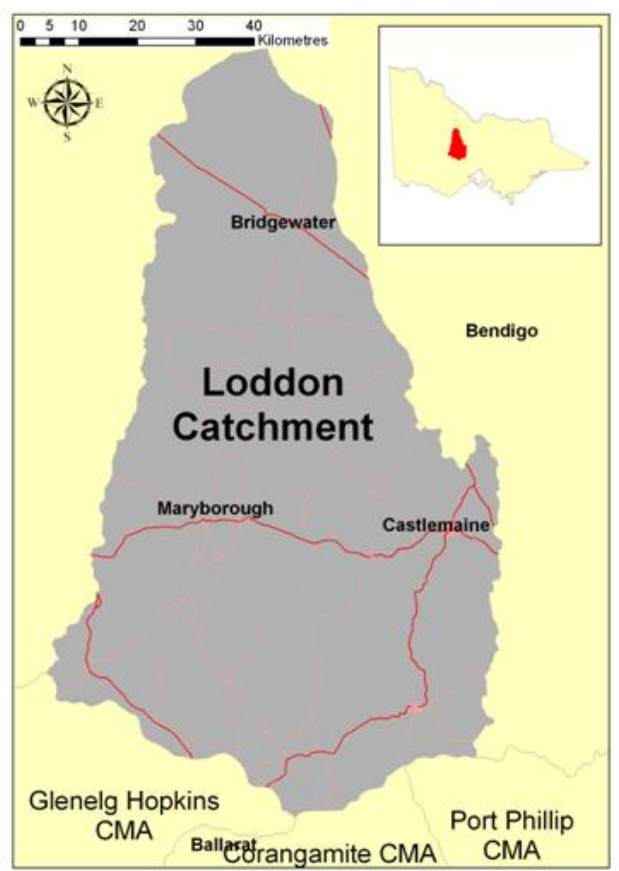

Figure 1: Location map of the Loddon catchment. 


\section{METHODOLOGY}

\subsection{Model framework}

The Catchment Analysis Tool (CAT) modelling approach described by Beverly et al. (2005) was applied to simulate the groundwater dynamics. This model comprises a combination of farming system models that account for topography, soil type, climate and land use linked into a catchment framework with connection to a distributed multi-layered groundwater model. The framework estimates the impact of various forms of intervention using a combination of paddock/farm scale models that are integrated into a regional catchment scale framework. Assigned to any landuse in the landuse layer is a farming system model capable of simulating the soil-water-plant interactions for any combination of land management with allowance for time varying landuse, crop rotations, fertiliser and irrigation regimes. Climate data accounts for position in the landscape and is based on the meteorological data measured at the nearest climate station. Recharge estimates are based on the volume of water that leaves the root zone and soil characteristics such as total soil depth and slope. Simulation and calibration of run-off and groundwater waterbalance enable informed accounting of the total water balance at both point and catchment scale.

In this application, the recharge estimates were used as input into the distributed multi-layered groundwater model MODFLOW (McDonald and Harbaugh, 1988). Modification to the MODFLOW model included the explicit incorporation of the landuse used in the surface hydrologic modelling to enable evaporation depth and rate to be spatially assigned to match the surface hydrologic model parameterization. The groundwater evaporation procedure was also modified to match the root extraction algorithms adopted by each of the farming system models embedded in CAT, as used to estimate surface hydrology and vegetation response. These modifications were necessary to ensure that total evapotranspiration did not exceed pan evaporation rates.

\subsection{Methods of GDE mapping}

A common method to map potential GDE is by interpreting satellite imagery. High resolution satellite information can be used to approximate actual evapotranspiration (ET $\mathrm{a}_{\mathrm{a}}$ (Kite and Droogers, 2000). Two alternative satellite technologies are generally utilised, namely Moderate resolution Imaging Spectradiometer (MODIS) and Surface Energy Balance Algorithm on Land (SEBAL). Both techniques approximate $\mathrm{ET}_{\mathrm{a}}$ as the residual when comparing net radiation with soil heat flux and sensible heat flux collected via satellite data (Bastiaansses et al., 1998; Mu et al., 2011; Bastiaansses et al., 2005). Both approaches require on-ground temperature, wind speed, relative humidity, solar radiation and local topography details (eg. aspect) to correct for local topographic variations. Dry season $\mathrm{ET}_{\mathrm{a}}$ outputs are generally used to define where a potential GDE occurs (Dresel et al., 2010; Bastiaanssen et al., 2005; Mu et al., 2011) (via either MODIS or SEBAL). This approach is based upon the concept that water usage must originate via groundwater in dry seasons.

An alternative approach of GDE mapping was undertaken by Brodie et al. (2007) in fractured basalt on the Alstonville Plateau of New South Wales. The mapping procedure utilised 1940's aerial photography, geology, geomorphology, streambed characteristics, stream buffers, vegetation mapping, point depth to watertable and considerable field investigation. The final map product was a classified ranking approach of GDE dependency where there was no clear attempt to correlate the GDE mapping with depth to watertable. That is, the mapping did not clearly distinguish between a deep $(>10 \mathrm{~m})$ and a shallow $(<10 \mathrm{~m})$ depth to watertable due to the lack of a GIS depth to watertable layer. As such, the GDE mapping was at best potential GDE based upon the resolution and linear buffer features of the mapping output.

\subsection{Model application}

Input spatial data layers required for the CAT modelling include: mean annual rainfall, mean annual temperature, climate station proximity, aspect, slope, elevation, land use and soils mapping. All input data layers were sampled to a 20 metre cell size. Groundwater simulations were based on a calibrated steady state model of the year 2000. The groundwater model was based on the previous model reported by Beverly and Hocking (2009) with grid refinement to a resolution of 50m. Key groundwater estimates required for this study include depth to watertable, groundwater discharge volumes to stream/drains, evaporation flux, groundwater abstraction and outflow volumes. 


\subsection{Model calibration}

Calibration of the framework involved the matching of simulated and catchment stream gauge data, groundwater hydrograph trends, and groundwater discharge areas. The farming system models used to derive recharge estimates and stream hydrograph responses for calibration have had considerable review, validation and application (Weeks et al., 2007). Calibration was consistent with the previous application.

\subsection{Scenario modelling to consider temporal response}

To better understand the potential variability of GDE mapping, two additional environmental scenarios were considered, namely the restoration of all vegetation to Ecological Vegetation Class (EVC) condition and a dry climate scenario (2000 to 2010 inclusive). The restoration of pre-European vegetation (with 2000 climate) as mapped by the EVC land use was based on an approach developed by Parkes et al. (2003). Change in runoff, shallow watertable area $<1.5$ metres and groundwater baseflow volume were recorded on a cell-by-cell basis across the model domain. The spatial patterning of evaporation rates and depths were also modified to match the relevant EVC class.

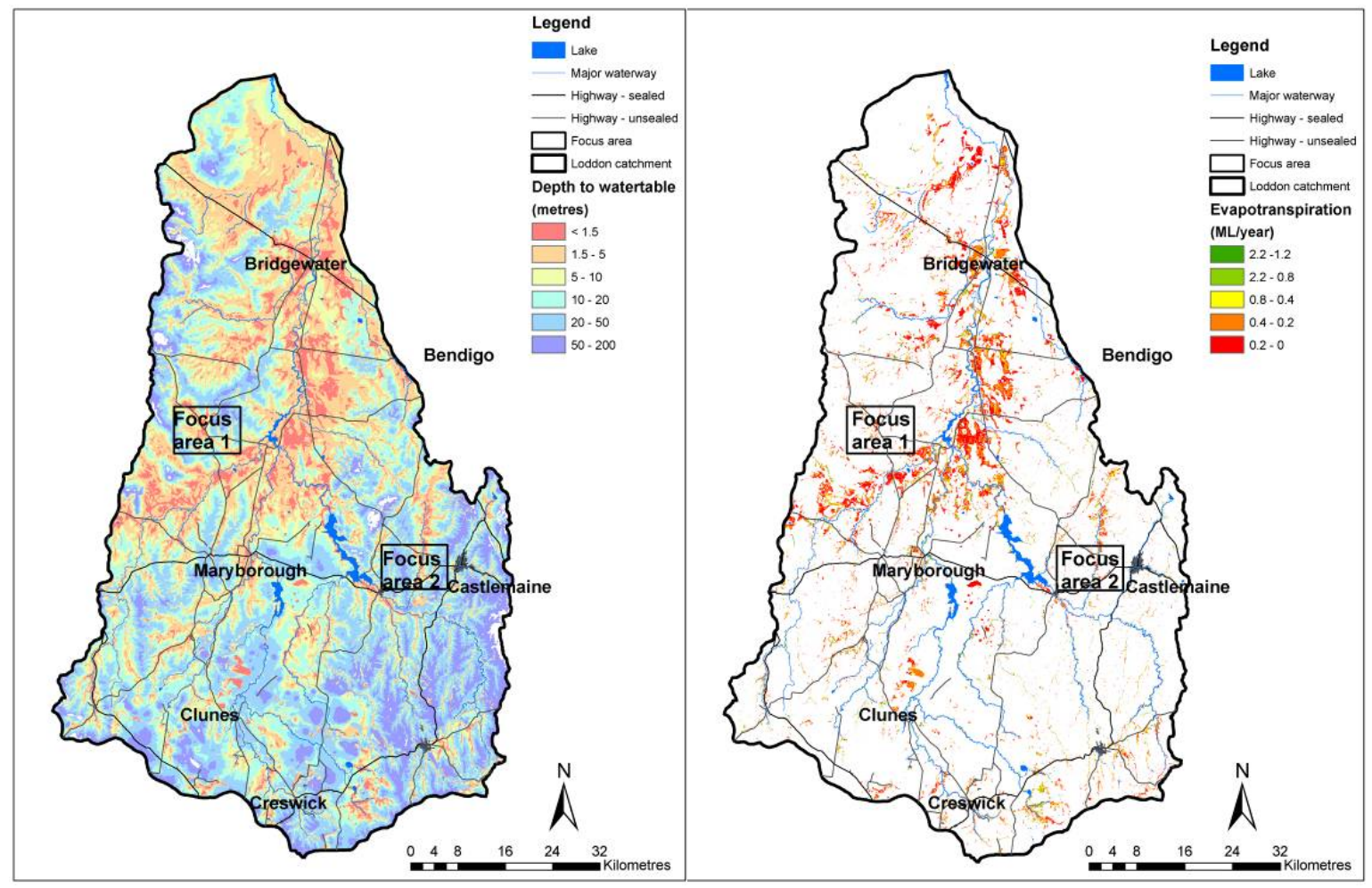

Figure 2: Simulated depth to watertable (m) (left) and mean annual groundwater evapotranspiration (ML/year) (white indicates no groundwater evaporation) (right). Also shown are the locations of the Eddington and Muckleford focus areas discussed in detail in this paper.

\section{RESULTS}

\subsection{Comparison of potential GDE mapping with simulated depth to watertable}

Simulated depth to watertable and associated mean annual groundwater evapotranspiration (ML/year) are shown in Figure 2. As expected, Figure 2 shows that the mean annual groundwater evapotranspiration fluxes are greatest in regions of shallow watertable. Comparison of the potential GDE mapping units (Dresel, et al., 2010) with the simulated depth to watertable for the same period show the extent of the potential GDE mapping far exceeds the area where depth to watertable is less than 10 metres (Figure 2).
Figure 3 presents a histogram of the depth to watertable information beneath the potential GDE mapping units and shows that while the overall data set is skewed toward a shallow watertable, there is a significant proportion of the sample set with a depth to watertable greater than the likely maximum vegetation rooting depth of 10 metres. The correlation coefficient between mapped potential GDE and depth to watertable $<10 \mathrm{~m},<5 \mathrm{~m}$ and $<2 \mathrm{~m}$ was $0.58,0.47$ and 0.27 respectively. 
The analysis of the potential GDE layer also identified that the simulated mean depth to watertable beneath mapped GDE units was 19.3 metres with a median watertable depth of 11.1 metres. Furthermore, Dresel et al., (2010) mapped a total of 64,472 hectares of potential GDE area. This is inconsistent with results from the detailed groundwater modelling shown in Figure 2, which estimates 49,910 ha experiences potential groundwater evapotranspiration across the catchment. Figure 4 presents a comparison of the simulated depth to watertable and potential GDE mapping at two focus sites, namely Eddington and Muckleford. The comparison shows many sites of shallow watertable occur outside the potential GDE mapped units. This is also the case with regards to the simulated groundwater evapotranspiration and potential GDE mapping as shown in Figure 5.

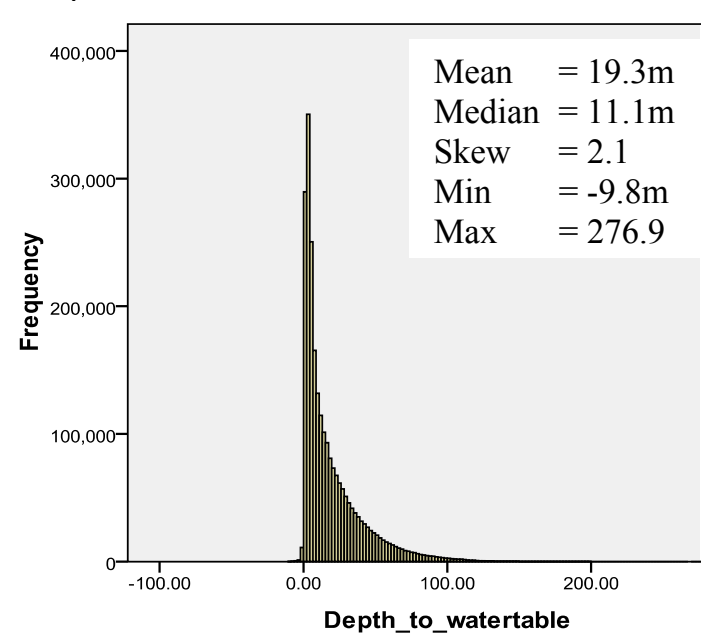

Figure 3: Histogram of the simulated depth to watertable beneath the potential GDE mapping units (metres).

\subsection{Comparison of potential GDE mapping with vegetation transpiration and soil moisture}

The correlation between mapped potential GDE zones across the catchment and vegetation transpiration from the unsaturated zone was found to be high (0.77) as shown in Figure 6 at the two focus sites. A similar correlation was found between mapped potential GDE zones and summer averaged soil saturation within the root zones ( 0.66 for soil saturation $>25 \%$ and 0.35 for soil saturation $>50 \%$ ).

\subsection{Scenario modelling}

Simulated shallow depth to watertable area and evapotranspiration (ET) results under differing environmental scenarios are summarised in Table 1. Results show that under pre-European conditions (as described by the EVC scenario) a much smaller shallow watertable area, ET area and ET volume are predicted. The cause of the reduced ET volume is attributed to an increased plant water-use in the soil profile and therefore less groundwater recharge in the water balance. Likewise, the dry climate scenario is predicted to decrease groundwater recharge. In contrast, a larger area of high shallow water table and extent of vegetation in connection with groundwater is predicted under current land use and average climate conditions relative to both the pre-European and dry climate conditions. The evapotranspiration rates from groundwater are similarly predicted to be higher. These results suggest that the extent of vegetation in connection with groundwater (and associated vegetative extraction volumes) under current land use are a function of land use, similar to that of secondary salinity occurrence. Therefore, the management of water balances to preserve and protect viable and significant ecological areas (or GDE areas) may also help control those areas with secondary salinity or water salinity issues.

\section{DISCUSSION}

Results indicate the current potential GDE mapping techniques have a high correlation with vegetation transpiration from the unsaturated zone and soil moisture status within the root zone, but poorly correlate with simulated depth to watertable. This suggests that the potential GDE mapping does not distinguish groundwater dependency from soil storage, lateral inflows and other processes. As such, the current potential GDE mapping approach is shown to (1) potentially overestimate extent, (2) be underpinned by large assumptions and low confidence in some of the key parameters (local climate) and (3) does not account for temporal fluctuations or groundwater connectivity. Given these outcomes, the current potential GDE mapping approach should not be used for management. The National Atlas GDE mapping project (Dowsley, et al., 2010) (note the lack of the term "potential" in the title) proposes to distinguish between an Inflow Dependent Ecosystem (IDE), whereby an IDE is associated with groundwater recharge (via surface flow or seepage), and GDEs. The method proposed to distinguish between GDE and IDE is not described. 


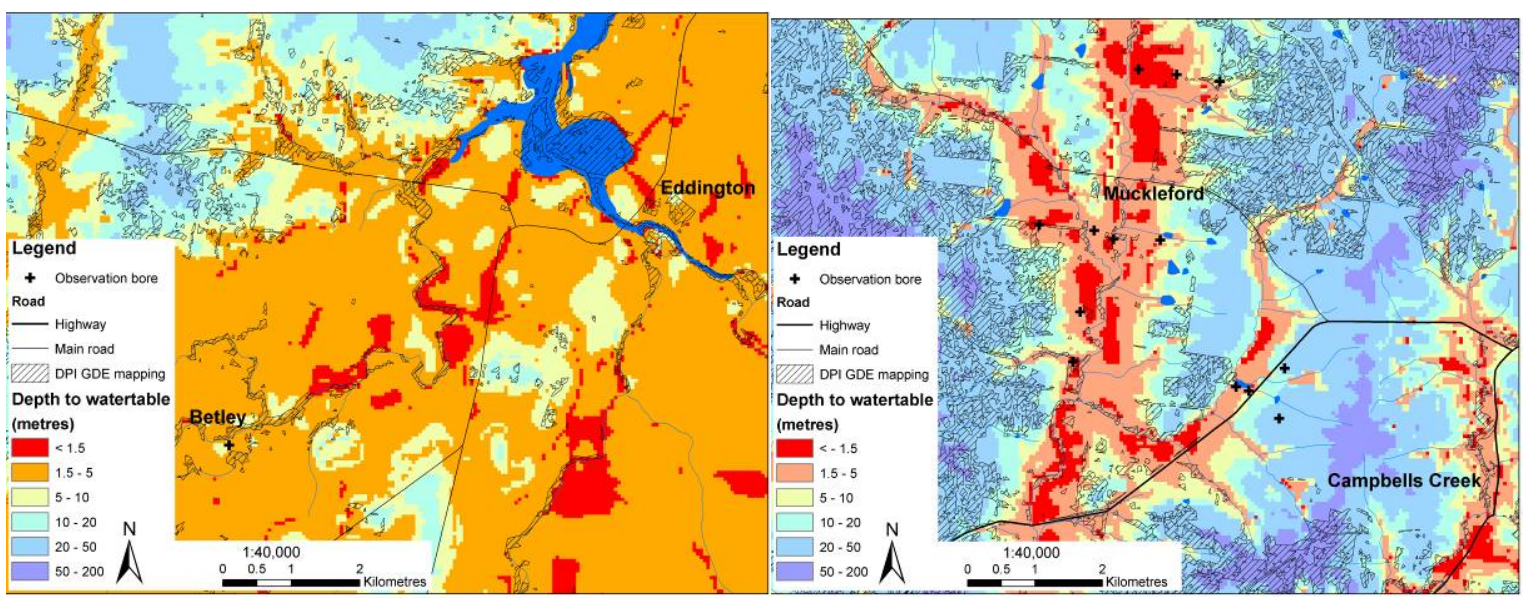

Figures 4: Simulated depth to watertable overlaid with potential GDE mapping at Eddington (left) and Muckleford (right)

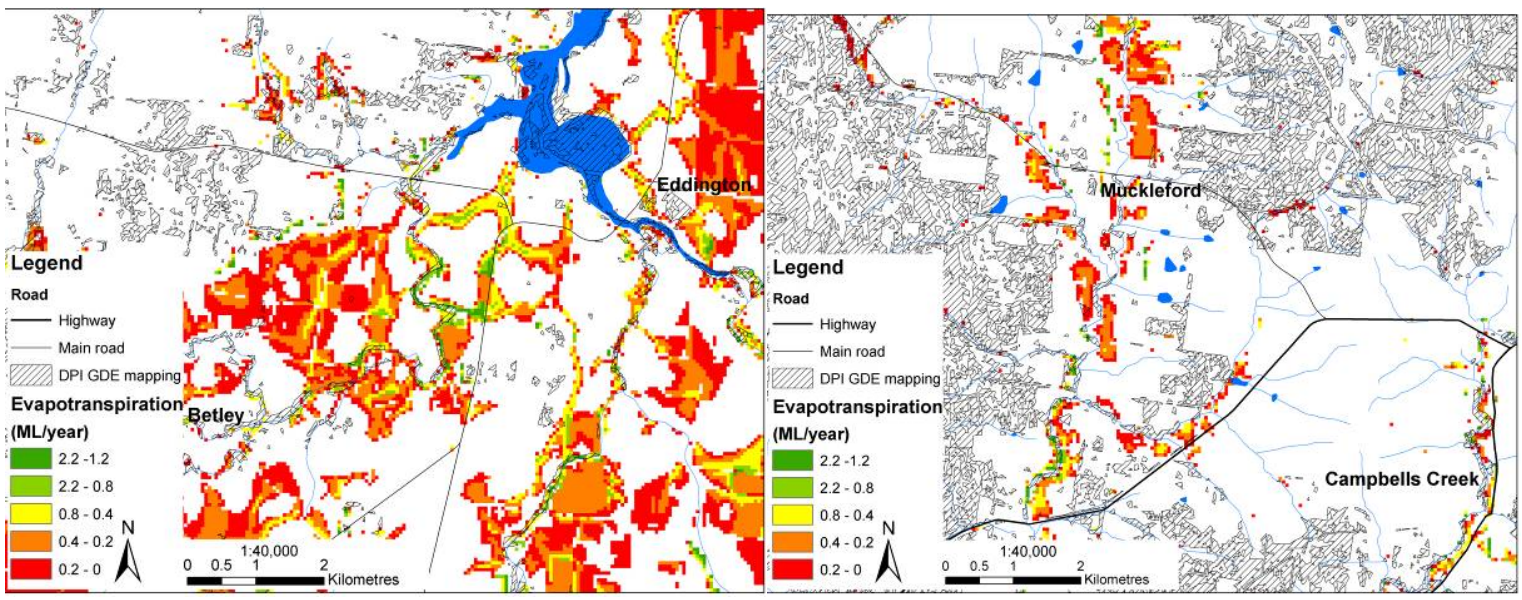

Figures 5: Simulated groundwater evapotranspiration overlaid with potential GDE mapping at Eddington (left) and Muckleford (right)

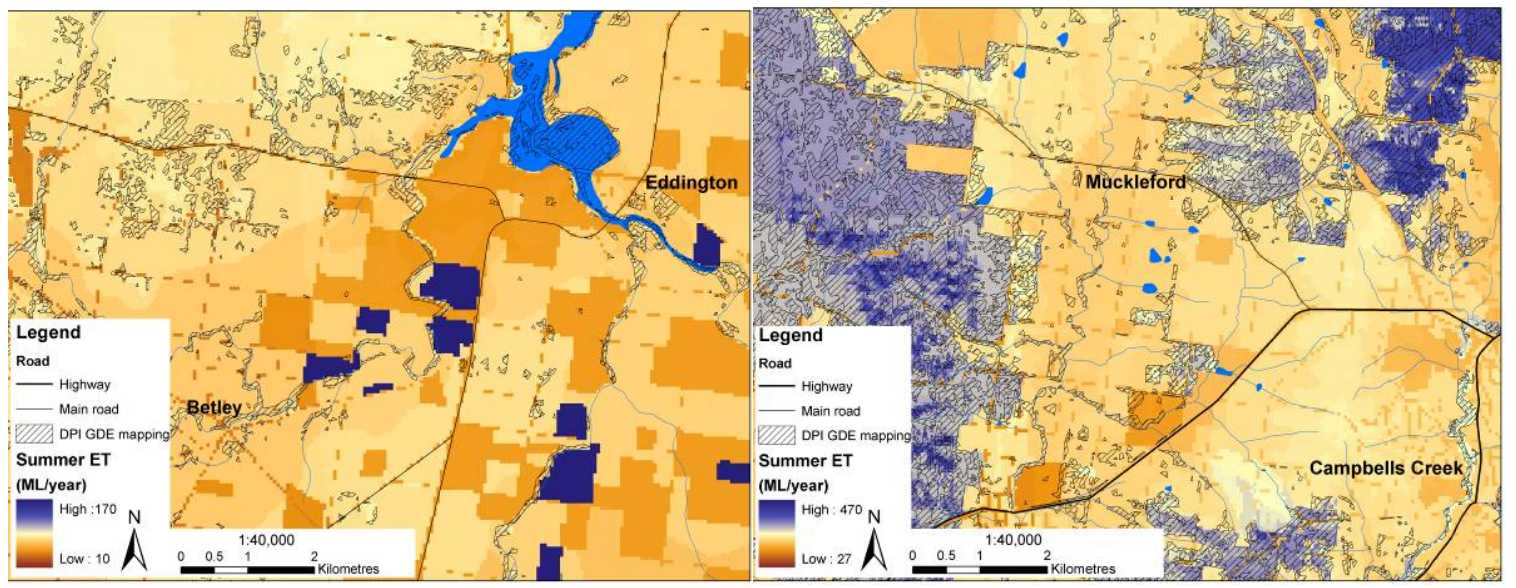

Figures 6: Simulated vegetation summer evapotranspiration (ET) overlaid with GDE mapping at Eddington (left) and Muckleford (right)

Table 1: Shallow watertable area and groundwater evapotranspiration extent and volumes under various land use and climate regimes.

\begin{tabular}{|l|c|c|c|}
\hline Environmental scenario & $\begin{array}{c}\text { Depth to watertable } \\
\text { (<2 metres) area (ha) }\end{array}$ & $\begin{array}{c}\text { Evapotranspiration area } \\
\text { (ha) }\end{array}$ & $\begin{array}{c}\text { Evapotranspiration } \\
\text { volume (GL/year) }\end{array}$ \\
\hline Current land use - 2003 & 68,080 & 44,910 & 4.3 \\
\hline Pre-European (EVC) & 29,002 & 18,429 & 0.7 \\
\hline Dry climate scenario & 49,324 & 31,458 & 2.1 \\
\hline
\end{tabular}




\section{CONCLUSIONS}

The application of the ranked approach of potential GDE mapping using remote sensing or aerial photography is shown to overestimate the likely GDE extent. It is important that the abbreviation of potential GDE to GDE should be avoided so as not to overstate the actual extent, significance and accuracy of the GDE mapped unit.

This paper raises the question of whether the current form of potential GDE mapping is adequate for groundwater resource management at the catchment scale. Results presented in this paper show significant variation between current GDE and EVC GDE mapped extents, which has significant implications for setting environmental condition targets. For example, potential GDE area has been estimated to be more than twice the area likely to be GDE, whereas the EVC scenario is almost half the evapotranspiration volume required by either the dry climate or average climate scenarios. The significance is that there may be as much as 3 times or more volume allocated to GDEs than required. Furthermore, the current management of catchment water balances to ensure potential GDE areas are preserved may also preserve nearby areas with secondary salinity or water salinity issues.

This study demonstrates detailed modelling could better describe, refine and distinguish GDE and IDE mapping.

\section{REFERENCES}

Bastiaanssen, W., Noordman, E., Pelgrum, H., Davids, G. and Allen, R. (2005). SEBAL for spatially distributed ET under actual management and growing conditions. J. Irr. Drain. Eng. 131, 85-93.

Bastiaanssen, W., Menenti, M., Feddes, A. and Holtslag, A. (1998). The Surface Energy Balance Algorithm for Land (SEBAL): Part 1 formulation. Journal of Hydrology. 212-213:198-212.

Beverly, C. and Hocking, M. (2009). Predicting groundwater response times and catchment impacts to landuse change. 18th World IMACS/MODSIM Congress, Cairns, Australia (13-17th July 2009), pp 18301836.

Beverly, C, Hocking, M., Wilford, J. and Lawrie, K. (2008). Building more robust hydrological models underpinned by new regolith-landform information. 2nd International Salinity Conference, Adelaide, April 29-March 52008.

Beverly, C., Bari, M., Christy, B., Hocking, M. and Smettem, K. (2005). Predicting salinity impacts from land use change: comparison between rapid assessment approaches and a detailed modelling framework. Australian Journal of Experimental Agriculture, 45, 1453-1469.

Dowsley, K., Fawcett, J., Richardson, S., Race, G., Mohamed-Ghouse, Z., Pitchard, J., Barron, G., Wallace, J., Van Dyke, A., Overton, I., Froend, R. and Auricht, A. (2010). Developing a National Atlas of groundwater dependent ecosystems. National Groundwater Conference 2010, Canberra, Abstract only.

Dresel, E., Clark, R., Cheng, X., Reid, M., Terry, A., Fawcett, J. and Cochrane, D. (2010). Mapping terrestrial groundwater dependent ecosystems: Method development and example output. Victorian Department of Primary Industries, Melbourne.

Harbaugh, A. and McDonald, M. (1996), User's documentation for MODFLOW-96, an update to the U.S. Geol. Surv. modular finite difference groundwater flow model: U.S. Geol. Surv. Open-File 90-485, 56p.

Kite, G. and Droogers, P. (2000). Comparing evapotranspiration from satellites, hydrological models and field data. Journal of Hydrology, 299, pp. 3-18.

$\mathrm{Mu}, \mathrm{Q}$., Zhoa, M. and Running, S. (2011). Improvements to a MODIS global terrestrial evaporation algorithm. Journal of Remote Sensing of Environment, 115, 1781-1800.

Parkes, D., Newell, G., Cheal, D. (2003) Assessing the Quality of Native Vegetation: The Habitat Hectares Approach. Ecological Management and Restoration, 4, S29-S38.

Parsons, S. and Caruso, N. (2010). The emergence of GDE management in Australia. National Groundwater Conference 2010, Canberra, Abstract only.

SKM (2000) Environmental water requirements of groundwater dependent ecosystems. Final Project Report to Environment Australia.

Weeks, A., Christy, B., Lowell, K., and Beverly, C. (2008). Catchment Analysis Tool (CAT) Demonstrating the benefits of interconnected biophysical models. In: Landscape Analysis and Visualisation. Spatial Models for NRM and Planning. (eds. Pettit, C., et al.) Springer- Verlag Publishers. 